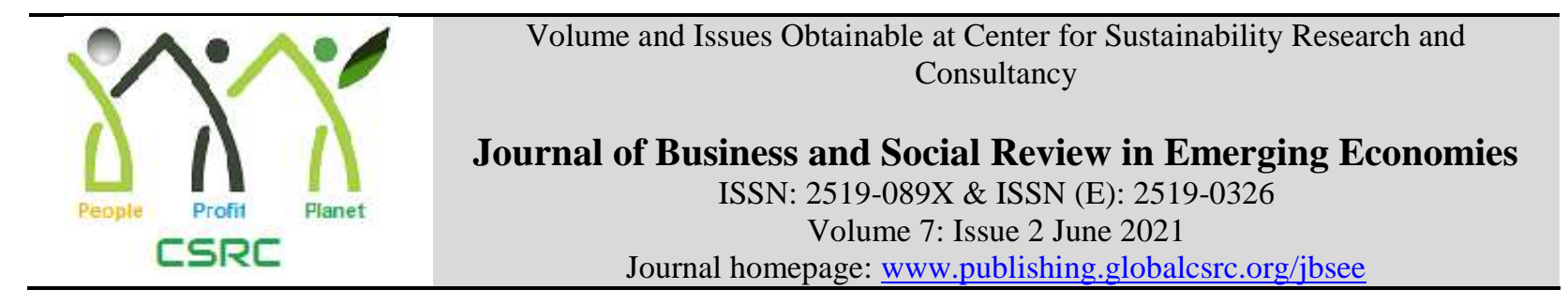

\title{
The Impact of Audit Committee Characteristics on Corporate Biodiversity Disclosure: An Analysis of Japanese Firms
}

\begin{abstract}
*Shahid Amin
\section{Jawad Iqbal} of Bahawalpur, Pakistan

\begin{tabular}{l}
\hline ARTICLE DETAILS \\
\hline History \\
Revised format: May 2021 \\
Available Online: Jun 2021
\end{tabular}

\section{Keywords \\ Corporate Biodiversity \\ Disclosure, \\ Audit Committee, \\ Gender Diversity, \\ Financial Expertise}

PhD Scholar, Institute of Business Management and Administrative Sciences, The Islamia University of Bahawalpur, Pakistan

Professor, Institute of Business Management and Administrative Sciences, The Islamia University

\section{Muhammad Abdul Majid Makki}

Professor, Department of Commerce, The Islamia University of Bahawalpur, Pakistan

*Corresponding author's email: shahid.amin@iub.edu.pk

\section{JEL Classification}

F23,M42 \begin{abstract}
Purpose: The loss of biodiversity is considered one of the greatest threats to economic development and human life. Business organizations have a direct impact on biodiversity through their operations. Therefore, the objective of the study is to examine the impact of audit committee (AC) characteristics on corporate biodiversity disclosure by using the data of Japanese listed firms.

Design/Methodology/Approach: This study is based on secondary data that has been collected from the corporate reports for the period 2012 to 2018. A final sample consists of 476 firmyear observations. Due to the nature of the data, panel regression (fixed-effects model) has been used to test the proposed hypotheses. Findings: The empirical results depict that the AC size, gender diversity, AC meetings, and financial expertise have a significant positive impact on corporate biodiversity disclosure. However, the AC independence and independence of the chair are not significant. Implications/Originality/Value: This is a unique study because no research study has examined the impact of AC characteristics on biodiversity disclosure as per the known literature. Thus, the findings of this study may help regulators, policymakers, investors, shareholders, and managers in assessing and monitoring the corporate biodiversity disclosure in light of AC characteristics.
\end{abstract}

(C) 2021 The authors, under a Creative Commons AttributionNonCommercial 4.0

Recommended citation: Amin, S., Iqbal, J., \& Makki, M. A. M. (2021). The Impact of Audit Committee Characteristics on Corporate Biodiversity Disclosure: An Analysis of Japanese Firms. Journal of Business and Social Review in Emerging Economies, 7(2), 239-254 


\section{Introduction}

The loss of biodiversity is considered one of the greatest threats to economic development and human life (Haque \& Jones, 2020; Roberts et al., 2021; Skouloudis et al., 2019). According to World Economic Forum (2021), the loss of biodiversity is ranked $4^{\text {th }}$ in the top ten global risks because it will have irrevocable penalties for human life, the natural environment, and economic activity. The scientific researchers believed that the planet has been reached in the sixth mass extinction where human activity is the primary driver (Maroun \& Atkins, 2018). Some experts also believe that up to one million animal species and plant face extinction within decades if precautionary measures are not taken (Brondizio et al., 2019; Roberts et al., 2021). Furthermore, according to Global Reporting Initiative (2016), business organizations, directly and indirectly, impact biodiversity. Due to these reasons, internal and external stakeholders put pressure on the business organizations to report and reduce their impact on biodiversity (Damayanti \& Syarifuddin, 2019; Global Reporting Initiative, 2016). Furthermore, stakeholders also expect that business organizations must recognize their responsibilities to protect the natural environment by developing sustainable policies; these policies assist the business to mitigate their negative environmental impact (Chung \& Parker, 2010). According to Solomon and Jones (2013), business organizations should be held responsible and accountable for their actions on biodiversity as the conservation of biodiversity is not only the responsibility of the government; business organizations are equally responsible for conserving the natural biodiversity though their operations. A number of consultancy firms argued that biodiversity conservation is the big challenge for the business organizations (KPMG, 2011) and organizations require managerial action to address the issue of biodiversity. However, the biodiversity gains the importance since 2010, consequently, the United Nations (UN) declared 2011-2020 as the decade of biodiversity (Haque \& Jones, 2020).

Business organizations have great potential to conserve the loss of biodiversity and the degradation of the natural environment (Krause \& Matzdorf, 2019; Solomon \& Jones, 2013). Furthermore, improvement in the world's natural assets is also the businesses' ethical responsibility (Jones \& Gaia, 2019). Therefore, corporate disclosures about biodiversity are essential sources of information to access a company's ability to address biodiversity environmental stewardship. Businesses need to work hard along with organizational resources to address the biodiversity challenges. In addition to this, firms can gain a competitive advantage by developing biodiversityfriendly policies. Therefore, according to Houdet et al. (2012), corporate boards are the key resources to address the sustainability agenda integrating with biodiversity issues. The most critical role of corporate governance (CG) is to ensure a firm's financial reporting quality. Moreover, Jamali et al. (2008) argued that corporate boards are more effective with sub-committees like audit committee (AC), sustainability committee, and compensation committee because the workload is shared with committee-based governance. The AC's primary function is to conduct the business's internal audit, including the audit of financial reports and its quality, with the attention to minimize asymmetric information between the business management and various stakeholders (Karamanou \& Vafeas, 2005). Thus, AC is an appropriate tool to monitor and to enhance the biodiversity disclosure.

In the literature, various studies have been conducted between the relationship of AC and CSR disclosures (Appuhami \& Tashakor, 2017; Buallay \& AlDhaen, 2018) and ignore the biodiversity dimension of CSR. Most of the research studies remained quite general in CSR but not focused on biodiversity (Boiral \& Heras-Saizarbitoria, 2017). Nevertheless, the existing literature has failed to address the effect of AC characteristics on corporate biodiversity disclosure; however, a few studies from the field of environmental sciences have explored the scientific dimensions of biodiversity (Reale et al., 2016). Therefore, this research study attempts to fill aforementioned gap by exploring the effect of AC characteristics on corporate biodiversity disclosure in the Japanese context. Japan 
is considered an appropriate avenue for this study because it has a powerful regulatory framework. Furthermore, the research will focus only on manufacturing firms because the manufacturing firms (especially using natural-resource-based raw material) can have a meaningful impact on biodiversity (Boiral \& Heras-Saizarbitoria, 2017). In the light of above discussion, the main aim of this research study is to empirically test the impact of AC attributes on corporate biodiversity disclosure.

The study makes the following contributions in literature. Firstly, we are among the first to empirically test the role of AC characteristics to address corporate biodiversity disclosure. Results indicate that $\mathrm{AC}$ size, gender diversity, AC meetings, and $\mathrm{AC}$ financial expertise significantly impact corporate biodiversity. Moreover, in the literature, most biodiversity studies are qualitative; however, this study is based on quantitative data to examine the role of $\mathrm{AC}$ in addressing biodiversity disclosure. The study is helpful for policymakers and regulators to amend the corporate governance code regarding AC.

\section{Literature Review and Hypothesis Development}

\section{AC Size}

AC size means the number of directors in the AC; it differs from country to country and company to company. According to Appuhami and Tashakor (2017), AC must be rich in diversity to monitor and report CSR activities like biodiversity disclosure. A higher number of directors in the AC have the essential strengths, diversity in knowledge, experience, and expertise that ensure appropriate internal monitoring, leading to better financial and non-financial disclosure (Bedard et al., 2004; Bédard \& Gendron, 2010; Zraiq \& Fadzil, 2018). Therefore, a higher number of AC directors assist the committee in exploring and resolving internal issues, specifically in the corporate reporting process (Buallay \& AlDhaen, 2018). On the other hand, larger committees size is not always in favor of the business. There are various supplementary costs linked with larger committees, such as poor communication, lack of coordination, and poor control (Jensen, 1993). Different Research studies have also noted that sub-committees with larger members can agonize with diffused responsibilities and suffer from free-rider ( $\mathrm{Li}$ et al., 2012).

The empirical evidence showed mixed results between the relationship of AC size and CSR or related disclosure e.g., Li et al. (2012) conducted a study by using the data of UK companies and found a significant relationship between AC size and intellectual capital disclosures. Likewise, Yang and Krishnan (2005) evidenced that AC size is positively linked with earnings management. Persons (2009) also concluded that AC size is an integral part of overseeing and improve voluntary corporate disclosure. However, some authors find no relationship between AC size and corporate disclosure (Mangena \& Tauringana, 2007). Based on these theoretical arguments and mixed results, we hypothesizes that:

$\mathrm{H}_{1}$ : Ceteris paribus, there is a significant positive relationship between AC size and the level of corporate biodiversity disclosure.

\section{AC Independence}

AC independence means the percentage of independent (outsider) directors in the AC. The director's independence is recognized globally as a key feature of AC in terms of improving in corporate financial and non-financial information (Appuhami \& Tashakor, 2017). Higher level of AC independence leads to better accountability and fair transparency (Pucheta-Martínez \& De Fuentes, 2007). Usually, the independent directors are knowledgeable, specialists in their field, and diversified experience that enriches the business organizations to take moral and sustainable decisions (Buallay \& AlDhaen, 2018). Biodiversity conservation and biodiversity disclosure is also 
the example of sustainable decisions. Therefore, this seems to argue that a higher level of AC independence encourages the firms to take independent decisions to improve biodiversity and CSR disclosure without any window-dressing.

Prior literature provides mixed results about AC independence and the level of financial and nonfinancial disclosure relationship. For example, Mangena and Tauringana (2007) conducted research using the sample of UK firms and found that AC independence is positively linked with corporate voluntary disclosure. Similarly, McMullen and Raghunandan (1996) also evidenced a significant positive relationship between AC independence and reporting quality. Furthermore, Kilgore et al. (2011) documented a significant positive effect of AC independence in reducing earnings management by using an Australian sample. In contrast, a few research studies found a negative or no association between AC independence and disclosure e.g., Li et al. (2012) conducted a survey using the UK dataset but found no association between AC independence and intellectual capital disclosure. Likewise, Yang and Krishnan (2005) also fail to establish any connection among AC independence and corporate earnings disclosure. Despite these mixed results, this study proposed a positive association between biodiversity disclosure and AC independence because there are no formal rules and regulation about biodiversity disclosure. Therefore, opportunistic managers may enhance information asymmetry in association to biodiversity conservation. Independent members of AC may get the benefit from the expedient behavior of manager by upgrading the efficacy of controlling process to improve biodiversity disclosure. Therefore, we hypothesize that:

$\mathrm{H}_{2}$ : Ceteris paribus, there is a significant positive relationship between AC independence and the level of corporate biodiversity disclosure.

\section{Gender Diversity}

A large number of research studies shed light on the problems linked with board gender (female) diversity in the subcommittees like AC (Agyei-Mensah Ben, 2019; Appuhami \& Tashakor, 2017; Haque \& Jones, 2020). Generally, it is assumed that gender diversity in subcommittees brings essential resources like human capital, social capital, creativity, and innovation that advance subcommittees' performance, such as disclosure reporting and monitoring (Carter et al., 2003). Furthermore, females who participate in sub-committees can be proactive in shaping a firm's environmental policy to mitigate global challenges such as loss of biodiversity and carbon emissions (Haque \& Jones, 2020). Female representation in the AC may perform a proactive role in enhancing the transparency of corporate financial reporting and CSR disclosure (Appuhami \& Tashakor, 2017). Research studies in corporate governance and accounting provide significant theoretical support about the association among AC gender diversity and a business's CSR disclosure. These empirical studies noted that corporate boards and sub-committees and female gender diversity can pay special attention to sensitive issues like CSR and biodiversity (Appuhami \& Tashakor, 2017; Gul et al., 2011). Female members of AC pressurize the business management to improve financial and non-financial disclosure like biodiversity (Gul et al., 2011). Based on these arguments, it is suggested that corporate board gender diversity in ACs enhances the committee's efficacy and level of biodiversity disclosure. Thus, the following hypothesis is being proposed:

$\mathrm{H}_{3}$ : Ceteris paribus, there is a significant positive association between the presence of female directors in $\mathrm{AC}$ and the corporate biodiversity disclosure.

\section{Independent $\mathrm{AC}$ chair}

One of the most crucial variables that affect the functioning of $\mathrm{AC}$ is the independence of its chair. The decisions of an AC are directly affected by AC chair as the chair is the responsible for the planning of entire agenda, AC meetings, coordinating with the board and other committees, setting 
the objectives of internal audit, and also outline entire audit activities (Appuhami \& Tashakor, 2017; Dwekat et al., 2020). Generally, it is suggested that the chairman/chair-person of an AC should be an independent person that have no chair or key position in corporate board. The rationale is that if the AC chair is independent in its role, the chair will have enough energy, time, and autonomy to make independent decision-making regarding financial and non-financial matters (Karamanou \& Vafeas, 2005). Therefore, AC chair independence enhances the level of environmental and sustainability disclosure(Appuhami \& Tashakor, 2017). Subsequently, GarcíaSánchez et al. (2012) argued that the separation in roles between AC chair and board chair may encourage AC members to improve monitoring function that could enhance the level of disclosure like CSR and biodiversity. However, a few studies examined the relationship between AC chair independence and the level of disclosure. For example, Beasley and Salterio (2001) argued that the presence or the interference of CEO or the board chairman in the AC has an adverse impact on the functioning of AC effectiveness. Similarly, Aldamen et al. (2012) and Ashfaq and Rui (2019) also argued that the AC chair should be independent to improve the transparency and disclosure of financial and non-financial reporting. Based on these arguments, we hypothesized that:

$\mathrm{H}_{4}$ : Ceteris paribus, there is a significant positive relationship between the presence of AC independent chair and the level of corporate biodiversity disclosure.

\section{Frequency of AC Meetings}

Board meeting frequency refers to the number of board meetings held during a fiscal year. Formal AC meetings improve the AC's effectiveness and provide enough time to committee members for the detailed discussion of all the matters (Appuhami \& Tashakor, 2017). The frequency of meetings is considered an assessment of AC due diligence (DeZoort et al., 2002). AC's that have meetings are more likely to point out and resolve the discrepancies to ensure sustainability disclosure's creditability like biodiversity(Appuhami \& Tashakor, 2017). Regular AC meetings assist the members in keeping informed and be proactive about biodiversity disclosure. Similarly, Karamanou and Vafeas (2005) concluded that a higher number of AC meetings improves the directors' monitoring function, improving a firm's disclosure policy like biodiversity disclosure. Abbott et al. (2004) also argued that a higher number of AC meetings improve the disclosure related to auditing, CSR, and accounting. Furthermore, empirical evidence also showed a significant positive relationship between AC meetings' frequency and a firm's financial and non-financial disclosure. For example, Kelton and Yang (2008) documented a significant positive relationship between the AC meetings and internet-based web disclosures. Pucheta-Martínez and De Fuentes (2007) conducted research using Spanish firms' data and found a significant positive association between the AC meetings and financial disclosures level. Further, Li et al. (2012) also evidenced a positive relationship between AC meetings and IC disclosure frequency. On the basis of these empirical evidences, it is concluded that ACs that have more frequency of meetings are better able to disclosure the information about CSR activities and biodiversity conservation. Therefore, this study hypothesizes that:

$\mathrm{H}_{5}$ : Ceteris paribus, there is a significant positive relationship between the frequency of AC meetings and the level of corporate biodiversity disclosure.

\section{AC's Financial Expertise}

Financial expertise in AC means the number of members who have financial qualifications like accounting and finance. Generally, it is assumed that members with financial expertise are more vulnerable to detect problems, frauds, and mistakes in financial and non-financial reports (Agrawal \& Chadha, 2005). Furthermore, AC members with financial qualifications understand reporting practices that comply with rules and regulations (Mangena \& Tauringana, 2007). Therefore, this study also argued that $\mathrm{AC}$ members with a financial qualification are likely to improve corporate biodiversity disclosure. Because the $\mathrm{AC}$ members with a financial qualification are in a better 
position to comprehend the need for voluntary disclosure to improve the business's ethical reputations ( $\mathrm{Li}$ et al., 2012). Research studies also observe that market stakeholders respond positively when business organizations appoint financial experts in AC (Bédard \& Gendron, 2010; DeFond \& Francis, 2005).

Previous research results also showed a positive relationship between the presence of financial directors in AC and voluntary corporate disclosure e.g., Mangena and Pike (2005) conducted research using the data of UK firms and found a significant positive connection between AC financial expertise and corporate interim disclosures. Likewise, Kelton and Yang (2008) evidenced that AC members with financial expertise enhance web-based disclosure in the US sitting. Furthermore, Mangena and Tauringana (2007) concluded that AC with financial expertise is more dedicated to complying with corporate various disclosure requirements. Similarly, Kent et al. (2010) also evidenced a positive association between AC's financial expertise and the corporate financial reporting. On the other hand, Appuhami and Tashakor (2017) found no association between AC financial expertise and CSR disclosure level. Due to this inconsistency in the literature, the following hypothesis is being proposed:

$\mathrm{H}_{6}$ : Ceteris paribus, there is a positive relationship between the percentage of AC members with financial qualification and the level of corporate biodiversity disclosure.

\section{Research Methodology}

\section{Sample and Data}

The main aim of the research is to examine the impact of AC characteristics on corporate biodiversity disclosure. To address this objective and test the proposed hypotheses, the study used Japanese listed firms' data. Japan is considered a promising avenue for this research because Japan is proactive in addressing environmental issues compared to other G7 countries. Another reason for choosing Japan is that the Japanese Ministry of Environment issued various corporate environmental reporting guidelines. According to these guidelines, companies are required to disclose biodiversity information. Furthermore, the study used the data from 2012 to 2018 due to various reasons. Firstly, in 2012 Japanese Ministry of Environment issued revised environmental reporting guidelines. Secondly, the GRI reporting guidelines also published a G3 version of reporting in 2012. According to this GRI guidelines version, business organizations are required to address the biodiversity issue. Initially, Nikkei 225 indexed firms were chosen, then removed the firms of financial and real estate sectors; moreover, the firms that have missing information also removed from the sample. Therefore, a final selection consists of 476 firm-year observations from the period 2012 to 2018 . The quantitative data have been collected from published corporate annual reports, e.g., annual reports, corporate social responsibility reports, and environmental reports.

\section{Measurement of Variables}

The dependent variable of this study is corporate biodiversity disclosure (BD). The study used the GRI (G3, G4) biodiversity indicators to examine the biodiversity disclosure as it covers maximum dimensions of biodiversity (Bhattacharyya \& Yang, 2019). According to GRI there are four biodiversity elements coded EN11, EN12, EN13, and EN14 in GRI reporting guidelines. In this study, we measured these indicators through binary coding; if the data of any indicator disclosed in corporate reports, then coded 1 otherwise 0 . Finally, an index has been developed by taking the average of all these four indicators.

Independent variables or the predictor variables are the characteristics of AC such as AC size (ACSIZE), AC independence (ACIND), gender diversity in AC (GENDER), independence of AC chair (INDCHAIR), AC meetings (ACMEET), financial experts in AC (FEXPRT). The ACSIZE 
is measured through the number of members in an audit committee. ACIND means the percentage of independent directors in the audit committee, whereas the GENDER is the percentage of female members in an AC. INDCHAIR is a binary variable coded 1 if the chairman is an independent director otherwise 0. ACMEET means the number of the meeting held by the audit committee during a year, whereas FEXPRT is the percentage of financial experts in an audit committee.

The study also used firm specific control variables such as research and development intensity (RDI) measured as the ratio of R\&D expenses to sales, leverage (LEV) the proportion of total liabilities to total assets, profitability measured through return on assets (ROA) and the firm size (FSIZE) measured though the natural log of total employees.

\section{Empirical Model}

To test the proposed hypothesis, the study used the balanced panel data. There are two regression estimation techniques for panel data - the fixed-effects model and the random-effects model. Hausman test is used to decide the appropriate model; the statistical values depict that the fixedeffect model is suitable for this study. Therefore, the multiple regression model of the study is estimated as follows:

$$
\begin{aligned}
\mathrm{BD}_{i t}= & \alpha+\beta_{1} \mathrm{ACSIZE}_{i t}+\beta_{2} \mathrm{ACIND}_{i t}+\beta_{3} \mathrm{GENDER}_{i t}+\beta_{4} \mathrm{INDCHAIR}_{i t}+\beta_{5} \mathrm{ACMEET}_{i t}+ \\
& \beta_{6} \mathrm{FEXPRT}_{i t}+u_{i t}
\end{aligned}
$$

Where, $\mathrm{BD}_{i t}$ is the corporate biodiversity disclosure $\mathrm{i}$ at time $\mathrm{ACSIZE}_{i t}$ is the audit committee size; $\mathrm{ACIND}_{i t}$ is the independence of audit committee; GENDER $i t$ is the audit committee gender diversity; INDCHAIR $i t$ is the independence of the AC chair; ACMEET $_{i t}$ is the number of AC meetings; FEXPRT $i t$ is the financial expertise of $\mathrm{AC}$ and $u_{i t}$ is the error term.

\section{Empirical Findings}

\section{Descriptive Statistics and Correlations Analysis}

Table 1 shows the results of descriptive statistics. Notably, the average score of biodiversity is almost $72 \%$, which implies a higher disclosure level. Because the sample of this study is based on the top Japanese firms listed in Nikkei 225 index. Regarding AC characteristics, the AC constituted a minimum of 2 members and a maximum of 7 members; furthermore, the audit committee has an average value of 4.618 members. On average, $52.3 \%$ are independent, $58 \%$ are female members who meet on average 13 times a year. Almost $61 \%$ of AC's have an independent chairman and, on average, $25 \%$ members with financial qualifications. Descriptive stats also indicate that Japanese companies spend almost $7 \%$ of sales in R\&D activities, and companies have nearly $54 \%$ debt. ROA demonstrates that some companies earn a profit, whereas certain companies are suffering in the loss. Skewness and kurtosis were also reported to check the normality of individual variables. All the values indicated that normality is not an issue in this study.

Table 2 shows the correlation values for all the variables. Mostly values of AC characteristics are positively correlated with biodiversity disclosure. Furthermore, all the correlation values are less than 0.8, which implies that multicollinearity is not an issue; VIF also verifies this because all the VIF values are less than 5 .

Table 1: Descriptive Statistics

\begin{tabular}{lrrrrrrr}
\hline & Obs. & Mean & Std. Dev. & min & max & skewness & kurtosis \\
\hline BD & 476 & .722 & .308 & 0 & 1 & -.739 & 2.47 \\
ACSIZE & 476 & 4.618 & .626 & 2 & 7 & -.785 & 1.305 \\
ACIND & 476 & 2.714 & .461 & 2 & 4 & -.819 & 2.03 \\
GENDER & 476 & .58 & .591 & 0 & 3 & .515 & 2.7 \\
INDCHAIR & 476 & .613 & .487 & 0 & 1 & -.466 & 1.217
\end{tabular}




\begin{tabular}{lrrrrrrr} 
MEET & 476 & 13.336 & 3.609 & 5 & 17 & 1.777 & 2.945 \\
FEXPRT & 476 & 1.607 & .802 & 0 & 4 & .604 & 2.637 \\
RDI & 476 & .07 & .095 & 0 & .74 & 3.969 & 2.01 \\
LEV & 476 & .54 & .174 & .115 & .961 & -.375 & 2.645 \\
ROA & 476 & .071 & .335 & -.811 & 4.049 & 9.656 & 1.005 \\
FSIZE & 476 & 9.997 & 1.171 & 7.327 & 12.819 & .294 & 2.916 \\
\hline
\end{tabular}


Table 2: Correlations Matrix

\begin{tabular}{|c|c|c|c|c|c|c|c|c|c|c|c|c|}
\hline Variables & VIF & 1 & 2 & 3 & 4 & 5 & 6 & 7 & 8 & 9 & 10 & 11 \\
\hline (1) $\mathrm{BD}$ & & 1.000 & & & & & & & & & & \\
\hline (2) ACSIZE & 2.06 & 0.039 & 1.000 & & & & & & & & & \\
\hline (3) ACIND & 1.96 & $0.095 * *$ & $0.377 * * *$ & 1.000 & & & & & & & & \\
\hline (4) GENDER & 1.21 & $0.296 * * *$ & $0.088 *$ & $0.122 * * *$ & 1.000 & & & & & & & \\
\hline (5) INDCHAIR & 1.09 & $0.088 *$ & 0.030 & 0.041 & $0.100 * *$ & 1.000 & & & & & & \\
\hline (6) ACMEET & 1.12 & $0.096 * *$ & 0.020 & $0.049 *$ & $0.137 * * *$ & $0.164 * * *$ & 1.000 & & & & & \\
\hline (7) FEXPRT & 1.07 & $0.068 *$ & 0.048 & 0.060 & $0.140 * * *$ & $0.117 * *$ & 0.049 & 1.000 & & & & \\
\hline (8) RDI & 1.91 & $0.156 * * *$ & 0.049 & $0.046^{*}$ & $0.093 * *$ & $0.115^{* *}$ & 0.059 & 0.047 & 1.000 & & & \\
\hline (9) LEV & 1.25 & $-0.146 * *$ & 0.057 & 0.013 & $0.199 * * *$ & 0.028 & $0.152 * * *$ & 0.042 & 0.070 & 1.000 & & \\
\hline (10) ROA & 1.53 & $0.092 * *$ & 0.061 & $0.057 * *$ & $0.103 * *$ & $0.088 *$ & 0.037 & 0.030 & $0.577 * * *$ & 0.017 & 1.000 & \\
\hline (11) FSIZE & 1.38 & $0.232 * * *$ & $0.261 * * *$ & $0.230 * * *$ & $0.238 * * *$ & $0.085 *$ & 0.013 & 0.005 & $0.117 * *$ & $0.343 * * *$ & $0.080 *$ & 1.000 \\
\hline
\end{tabular}




\section{Regression Analysis Results}

Table 3, Model 1 shows the impact of firm-specific control variables on biodiversity disclosure. The statistical values evidenced that all the control variables are positively significant. The RDI is positively significant at $5 \%$ level of significance $(\beta=0.568, p<0.05)$. This indicates the biodiversity disclosure will be increased with an increase in research and development spending. Similarly, RDI is also positively significant at $5 \%$ level of significance $(\beta=0.274, p<0.05)$. This implies that an increase in research and development expenditure tends to positively impact biodiversity disclosure. Furthermore, the coefficient of leverage is negative but statistically significant. These findings are similar to Bhattacharyya and Yang (2019) and Hassan et al. (2020), which infers that an increase in the business financial risk leads to a reduction in biodiversity disclosure. In addition to this, profitability and firm size also have positive significance $(R O A \beta=$ 0.166, $p<0.01$; FSIZE $\beta=0.0712, p<0.1)$ impact of corporate biodiversity disclosure in the Japanese context, these results are similar to Aldamen et al. (2012) and Bhattacharyya and Yang (2019). These results evidenced that the firm that is rich in profitability has excellent potential to disclose biodiversity issues. Moreover, the firms that are larges in size also have a positive impact on biodiversity disclosure.

Model 2 of Table 3 presents regression results of audit committee attributes on corporate biodiversity disclosure. The statistical results indicate that audit committee size, audit committee gender diversity, audit committee meetings, and audit committee financial expertise have a significant positive impact on biodiversity disclosure. In contrast, both the audit committee independence and audit committee chair independence are not significant. The beta coefficient of audit committee size is positively significant with biodiversity disclosure at a $5 \%$ level of significance $(\beta=0.0994, p<0.05)$. Thus, hypothesis $\mathrm{H} 1$ is accepted. This predicts that the larger audit committees are playing a proactive role in disclosing biodiversity information. The reason is that larger committees are more diversified in terms of knowledge, experience, and expertise, which can address biodiversity issues better. These findings are consistent with the studies of Appuhami and Tashakor (2017) and Buallay and AlDhaen (2018). The second hypothesis is about audit committee independence; it is hypothesized that audit committee independence is positively associated with biodiversity disclosure. The statistical results are not significant at any level of significance $(\beta=0.0774, p>0.1)$; therefore, $\mathrm{H} 2$ is not accepted. These findings are similar to research studies of Li et al. (2012) and Zou et al. (2015). It is depicted that independent directors in $\mathrm{AC}$ are not meant to improve biodiversity disclosure. Furthermore, the findings are influential in the Japanese context because Japan follows hybrid corporate governance (Endo, 2020), independent directors focus on shareholders protection. 
Table 3: Regression Results

\begin{tabular}{|c|c|c|c|}
\hline VARIABLES & $\begin{array}{l}\text { Model } 1 \\
\text { Control }\end{array}$ & $\begin{array}{c}\text { Model } 2 \\
\text { FE }\end{array}$ & $\begin{array}{c}\text { Model } 3 \\
\text { FE-Robust }\end{array}$ \\
\hline ACSIZE & & $\begin{array}{c}0.0994 * * \\
(0.0400)\end{array}$ & $\begin{array}{c}0.0994 * * \\
(0.0488)\end{array}$ \\
\hline ACIND & & $\begin{array}{c}0.0774 \\
(0.0504)\end{array}$ & $\begin{array}{c}0.0774 \\
(0.0548)\end{array}$ \\
\hline GENDER & & $\begin{array}{c}0.139 * * * \\
(0.0369)\end{array}$ & $\begin{array}{l}0.139 * * \\
(0.0530)\end{array}$ \\
\hline INDCHAIR & & $\begin{array}{c}0.0273 \\
(0.0279)\end{array}$ & $\begin{array}{c}0.0273 \\
(0.0395)\end{array}$ \\
\hline ACMEET & & $\begin{array}{c}0.0191 * * * \\
(0.00593)\end{array}$ & $\begin{array}{l}0.0191 * * \\
(0.00722)\end{array}$ \\
\hline FEXPRT & & $\begin{array}{c}0.0611 * * * \\
(0.0177)\end{array}$ & $\begin{array}{c}0.0611 * * \\
(0.0266)\end{array}$ \\
\hline RDI & $\begin{array}{c}0.568 * * \\
(0.262)\end{array}$ & $\begin{array}{c}0.544 * * \\
(0.252)\end{array}$ & $\begin{array}{c}0.544 * * \\
(0.273)\end{array}$ \\
\hline LEV & $\begin{array}{c}-0.274 * * \\
(0.114)\end{array}$ & $\begin{array}{c}-0.182 * * \\
(0.0927)\end{array}$ & $\begin{array}{l}-0.182 * \\
(0.102)\end{array}$ \\
\hline ROA & $\begin{array}{c}0.166^{* * * *} \\
(0.0444)\end{array}$ & $\begin{array}{c}0.146 * * * \\
(0.0450)\end{array}$ & $\begin{array}{c}0.146 * * * \\
(0.0245)\end{array}$ \\
\hline FSIZE & $\begin{array}{l}0.0712 * \\
(0.0421)\end{array}$ & $\begin{array}{c}0.0895 * * \\
(0.0404)\end{array}$ & $\begin{array}{l}0.0895^{*} \\
(0.0508)\end{array}$ \\
\hline Constant & $\begin{array}{c}0.826 * * * \\
(0.225)\end{array}$ & $\begin{array}{c}0.626 * * * \\
(0.152)\end{array}$ & $\begin{array}{c}0.626 * * * \\
(0.242)\end{array}$ \\
\hline R-squared & 0.153 & 0.254 & 0.254 \\
\hline Observations & 476 & 476 & 476 \\
\hline
\end{tabular}

Generally, it is assumed that gender diversity in subcommittees brings essential resources like human capital, social capital, creativity, and innovation that advance subcommittees' performance, such as disclosure reporting and monitoring (Carter et al., 2003). Furthermore, female members in sub-committees can be proactive in shaping a firm's environmental policy to mitigate global challenges such as loss of biodiversity and carbon emissions (Haque \& Jones, 2020). Similarly, in this study, the coefficient of gender diversity is positively significant at the $1 \%$ level of significance $(\beta=0.139, p>0.01)$; thus, hypothesis 3 is accepted. These findings are consistent with the studies of Gul et al. (2011) and Appuhami and Tashakor (2017). The empirical results indicate that the AC committee performs better in the presence of female members because the female director can initiate and implement sustainable corporate business that may reduce the loss of biodiversity. The following hypothesis is about chairman independence. It is assumed that an independent chairman of the audit committee can be more effective in disclosing biodiversity disclosure. But the empirical results are contradictory. The chair independence coefficient is not significant $(\beta=0.0273, p>$ 0.1 ); therefore, hypothesis 4 is rejected. The findings are not similar to the studies of Aldamen et al. (2012) and Ashfaq and Rui (2019); thus, we infer that the AC independence is not playing a positive role in disclosing biodiversity information.

The activeness of $\mathrm{AC}$ is measured through the number of $\mathrm{AC}$ meetings; it is assumed that a higher number of board meetings will improve the biodiversity disclosure. The statistical results support this argument. The number of AC meeting's beta coefficient is positive and highly significant $(\beta=$ 
0.0191, $p<0.01$ ). Therefore, we accept hypothesis 5. Based on these findings, it is inferred that a higher number of AC meetings will resolve the discrepancies and ensured the creditability of biodiversity discourses. These findings are similar to the studies of Karamanou and Vafeas (2005), Kelton and Yang (2008), Li et al. (2012), and Appuhami and Tashakor (2017). The last hypothesis is about the relationship of financial experts in AC and biodiversity discourses. It is hypothesized that there is a positive relationship between financial experts and biodiversity disclosure. Similarly, the empirical evidence supports this argument as the coefficient is significant at a $1 \%$ level of significance $(\beta=0.0611, p<0.01)$. Thus, we accept hypothesis 6 and conclude that the higher percentage of $\mathrm{AC}$ members with financial qualifications tends to disclose more information about biodiversity. Finally, Model 3 present the results with robust standard errors. All the results are similar to the fixed-effects model, which depicts the fitness of statistical results.

\section{Conclusion}

The objective of this research is to examine empirically the impact of AC attributes on the level of corporate biodiversity disclosure by using the data of listed firms. The empirical results identified that AC attributes like audit committee size, gender diversity, AC meetings, and AC members' financial expertise are significant and positively contribute in improving biodiversity disclosure. However, there is no evidence to support the postulation that AC member independence and AC chair independence influence corporate biodiversity disclosure in corporate reports. Based on these empirical findings, it is concluded that AC characteristics improve biodiversity disclosure level, even in the absence of mandatory disclosure requirements. Furthermore, these findings also depict that AC characteristics give the stakeholders a signal that AC can control and monitor non-financial discoursers like biodiversity. Similarly, these findings support the augment of Jamali et al. (2008) that $\mathrm{AC}$ is a key pillar of corporate governance address CSR and environmental orientations.

The findings of this research may be benefitted for policymakers and regulators to amend in the corporate governance code with reference to AC. In particular, the study noted that gender diversity, committee meetings, and financial expertise are highly significant; thus, it infers that business organizations should pay special attention to these characteristics of AC. Due to continuous pressures from stakeholders, the policy makers and the business regulators may also consider introducing mandatory biodiversity disclosure requirements under AC's supervisory role. Despite a significant contribution and implications, the study is not free from limitations; therefore, these limitations should be acknowledged while interpreting this research's findings. Firstly, the study empirically examined the impact of AC characteristics on biodiversity disclosure only of listed Japanese firms and ignored the non-listed firms and other countries' firms; therefore, future research may be conducted by including non-listed companies and the companies of multiple countries as well. Secondly, the biodiversity disclosure is based on GRI guidelines. The data has been collected only from corporate annual reports, whereas other sources such as newspapers, media exposure, and websites are ignored. In future research, comprehensive biodiversity data may be collected from multiple sources to cover all corporate biodiversity dimensions. As discussed earlier, the stakeholders put pressure on business organizations to disclose biodiversity information; thus, the role of stakeholders' engagement may also be explored in future research.

\section{References}

Abbott, L. J., Parker, S., \& Peters, G. F. (2004). Audit committee characteristics and restatements. Auditing: A journal of practice \& theory, 23(1), 69-87.

Agrawal, A., \& Chadha, S. (2005). Corporate governance and accounting scandals. The Journal of Law and Economics, 48(2), 371-406.

Agyei-Mensah Ben, K. (2019). The effect of audit committee effectiveness and audit quality on corporate voluntary disclosure quality. African Journal of Economic and Management Studies, 10(1), 17-31. doi:10.1108/AJEMS-04-2018-0102 
Aldamen, H., Duncan, K., Kelly, S., McNamara, R., \& Nagel, S. (2012). Audit committee characteristics and firm performance during the global financial crisis. Accounting \& Finance, 52(4), 971-1000.

Appuhami, R., \& Tashakor, S. (2017). The impact of audit committee characteristics on CSR disclosure: An analysis of Australian firms. Australian Accounting Review, 27(4), 400-420.

Ashfaq, K., \& Rui, Z. (2019). The effect of board and audit committee effectiveness on internal control disclosure under different regulatory environments in South Asia. Journal of Financial Reporting and Accounting.

Bedard, J., Chtourou, S. M., \& Courteau, L. (2004). The effect of audit committee expertise, independence, and activity on aggressive earnings management. Auditing: A journal of practice \& theory, 23(2), 13-35.

Bédard, J., \& Gendron, Y. (2010). Strengthening the financial reporting system: Can audit committees deliver? International Journal of Auditing, 14(2), 174-210.

Bhattacharyya, A., \& Yang, H. (2019). Biodiversity disclosure in Australia: effect of GRI and institutional factors. Australasian Journal of Environmental Management, 26(4), 347-369.

Boiral, O., \& Heras-Saizarbitoria, I. (2017). Best practices for corporate commitment to biodiversity: An organizing framework from GRI reports. Environmental Science \& Policy, 77, 77-85.

Brondizio, E. S., Settele, J., Díaz, S., \& Ngo, H. T. (2019). Global assessment report on biodiversity and ecosystem services of the Intergovernmental Science-Policy Platform on Biodiversity and Ecosystem Services. IPBES secretariat, Bonn, Germany.

Buallay, A. M., \& AlDhaen, E. S. (2018). The relationship between audit committee characteristics and the level of sustainability report disclosure. Paper presented at the Conference on eBusiness, e-Services and e-Society, Springer, Cham.

Carter, D. A., Simkins, B. J., \& Simpson, W. G. (2003). Corporate governance, board diversity, and firm value. Financial review, 38(1), 33-53.

Chung, L. H., \& Parker, L. D. (2010). Managing social and environmental action and accountability in the hospitality industry: A Singapore perspective. Accounting Forum, 34(1), 46-53. doi:https://doi.org/10.1016/j.accfor.2009.10.003

Damayanti, R. A., \& Syarifuddin, S. (2019). Biodiversity accounting: uncover environmental destruction in Indonesia. Social Responsibility Journal, 16(6), 809-825. doi:10.1108/SRJ11-2018-0291

DeFond, M. L., \& Francis, J. R. (2005). Audit research after sarbanes-oxley. Auditing: A journal of practice \& theory, 24(s-1), 5-30.

DeZoort, F. T., Hermanson, D. R., Archambeault, D. S., \& Reed, S. A. (2002). Audit committee effectiveness: A synthesis of the empirical audit committee literature. Audit Committee Effectiveness: A Synthesis of the Empirical Audit Committee Literature, 21, 38.

Dwekat, A., Seguí-Mas, E., Tormo-Carbó, G., \& Carmona, P. (2020). Corporate governance configurations and corporate social responsibility disclosure: Qualitative comparative analysis of audit committee and board characteristics. Corporate Social Responsibility and Environmental Management, 27(6), 2879-2892.

Endo, K. (2020). Corporate governance beyond the shareholder-stakeholder dichotomy: Lessons from Japanese corporations' environmental performance. Business Strategy and the Environment, 29(4), 1625-1633.

García-Sánchez, I. M., Frias-Aceituno, J. V., \& Garcia-Rubio, R. (2012). Determining factors of audit committee attributes: Evidence from Spain. International Journal of Auditing, 16(2), 184-213.

Global Reporting Initiative, G. (2016). GRI 304: BIODIVERSITY. Retrieved from Amsterdam, The Netherlands, Access Date: December 2020: https://www.globalreporting.org/standards/media/1011/gri-304-biodiversity-2016.pdf

Gul, F. A., Srinidhi, B., \& Ng, A. C. (2011). Does board gender diversity improve the informativeness of stock prices? Journal of accounting and Economics, 51(3), 314-338. 
Haque, F., \& Jones, M. J. (2020). European firms' corporate biodiversity disclosures and board gender diversity from 2002 to 2016. The British Accounting Review, 100893.

Hassan, A. M., Roberts, L., \& Atkins, J. (2020). Exploring factors relating to extinction disclosures: What motivates companies to report on biodiversity and species protection? Business Strategy and the Environment, 29(3), 1419-1436.

Houdet, J., Trommetter, M., \& Weber, J. (2012). Understanding changes in business strategies regarding biodiversity and ecosystem services. Ecological Economics, 73, 37-46.

Jamali, D., Safieddine, A. M., \& Rabbath, M. (2008). Corporate governance and corporate social responsibility synergies and interrelationships. Corporate Governance: An International Review, 16(5), 443-459.

Jensen, M. C. (1993). The modern industrial revolution, exit, and the failure of internal control systems. the Journal of Finance, 48(3), 831-880.

Jones, M. J., \& Gaia, S. (2019). Biodiversity reporting for governmental organisations. Accounting, Auditing \& Accountability Journal, 33(1), 1-31. doi:10.1108/AAAJ-05-2018-3472

Karamanou, I., \& Vafeas, N. (2005). The association between corporate boards, audit committees, and management earnings forecasts: An empirical analysis. Journal of Accounting research, 43(3), 453-486.

Kelton, A. S., \& Yang, Y.-w. (2008). The impact of corporate governance on Internet financial reporting. Journal of accounting and Public Policy, 27(1), 62-87.

Kent, P., Routledge, J., \& Stewart, J. (2010). Innate and discretionary accruals quality and corporate governance. Accounting \& Finance, 50(1), 171-195.

Kilgore, A., Sil Kang, W., \& Wright, S. (2011). The effectiveness of audit committees for low- and mid-cap firms. Managerial Auditing Journal, 26(7), 623-650. doi:10.1108/02686901111151341

KPMG. (2011). Sustainable Insight. The Nature of Ecosystem Service Risks for Business. KPMG. Amstelveen, The Netherlands. Retrieved from http://www.unepfi.org/fileadmin/documents/Sustainable_Insight_May_2011.pdf

Krause, M. S., \& Matzdorf, B. (2019). The intention of companies to invest in biodiversity and ecosystem services credits through an online-marketplace. Ecosystem Services, 40, 101026. doi:https://doi.org/10.1016/j.ecoser.2019.101026

Li, J., Mangena, M., \& Pike, R. (2012). The effect of audit committee characteristics on intellectual capital disclosure. The British Accounting Review, 44(2), 98-110.

Mangena, M., \& Pike, R. (2005). The effect of audit committee shareholding, financial expertise and size on interim financial disclosures. Accounting and Business Research, 35(4), 327349.

Mangena, M., \& Tauringana, V. (2007). Corporate compliance with non-mandatory statements of best practice: the case of the ASB statement on interim reports. European Accounting Review, 16(2), 399-427.

Maroun, W., \& Atkins, J. (2018). The emancipatory potential of extinction accounting: Exploring current practice in integrated reports. Accounting Forum, 42(1), 102-118. doi:https://doi.org/10.1016/j.accfor.2017.12.001

McMullen, D. A., \& Raghunandan, K. (1996). Enhancing audit committee effectiveness. Journal of Accountancy, 182(2), 79.

Persons, O. S. (2009). Audit committee characteristics and earlier voluntary ethics disclosure among fraud and no-fraud firms. International journal of disclosure and governance, 6(4), 284-297.

Pucheta-Martínez, M. C., \& De Fuentes, C. (2007). The impact of audit committee characteristics on the enhancement of the quality of financial reporting: An empirical study in the Spanish context. Corporate Governance: An International Review, 15(6), 1394-1412.

Reale, R., Ribas, L. C., Borsato, R., Magro, T. C., \& Voigtlaender, M. (2016). The LIFE certification methodology as a diagnostic tool of the environmental management system of the automotive industry. Environmental Science \& Policy, 57, 101-111. 
Roberts, L., Hassan, A., Elamer, A., \& Nandy, M. (2021). Biodiversity and extinction accounting for sustainable development: A systematic literature review and future research directions. Business Strategy and the Environment, 30(1), 705-720.

Skouloudis, A., Malesios, C., \& Dimitrakopoulos, P. G. (2019). Corporate biodiversity accounting and reporting in mega-diverse countries: An examination of indicators disclosed in sustainability reports. Ecological Indicators, 98, 888-901.

Solomon, J. F., \& Jones, M. J. (2013). Problematising accounting for biodiversity. Accounting, Auditing \& Accountability Journal, 26(5), 668-687. doi:10.1108/AAAJ-03-2013-1255

World Economic Forum, W. (2021). The Global Risks Report 2021. Retrieved from Geneva, Switzerland March 20, 2021: https://www.weforum.org/reports/the-global-risks-report$\underline{2021}$

Yang, J. S., \& Krishnan, J. (2005). Audit committees and quarterly earnings management. International Journal of Auditing, 9(3), 201-219.

Zou, H., Zeng, S., Xie, L., \& Zeng, R. (2015). Are top executives rewarded for environmental performance? The role of the board of directors in the context of China. International Review of Applied Economics, 21(6), 1542-1565.

Zraiq, M., \& Fadzil, F. (2018). The impact of audit committee characteristics on firm performance: Evidence from Jordan. Sch J Appl Sci Res, 1(5), 39-42. 
